\title{
IMPROVEMENT OF CREATIVE THINKING AT STUDENTS IN HIGHER EDUCATION INSTITUTIONS
}

\author{
Umida Marasulova \\ Shakhrisabz branch of Tashkent State, Pedagogical University named after Nizami, Deputy \\ Director for Science and Innovation, Ph.D.
}

Diyora Abdurahimova

Student of Uzbek State World Languages University.

Article DOI: https://doi.org/10.36713/epra1833

\begin{abstract}
ANNOTATION
The article provides an overview of creative types of training. There are ideas about how pedagogical methods should be used in the formation of students' creative thinking in higher education.

KEY WORDS: Creativity, pedagogy, creative pedagogy. The main categories of science, research methods, creativity, thinking, critical thinking.
\end{abstract}

\section{DISCUSSION}

Not so long ago in modern pedagogy the concept of "creative pedagogy" began to be applied. Nevertheless, the need to develop innovative and creative approaches to the learning process guaranteed that "Creative Pedagogy" became an independent subject among pedagogical disciplines. The basis of this subject is the methodological representations of such disciplines as the history of pedagogy, general and professional pedagogy and psychology, methods of teaching private disciplines, educational technologies and professional ethics. The general fundamentals of the subject "Creative Pedagogy" provide the necessary conditions for the professional development of specialists, including future specialists.

The formation and development of a creative person is based on the coordination of his inner and outer world, socio-economic conditions and the content of his work - from birth to the end of his life, which requires continuity. The creation of a creative person can be defined as the development of a person through mutual creative actions and creative products. The pace and scale of this process depends on the biological and social factors, activity and creative qualities of a person, as well as on current conditions, life-changing and professionally determined events. In modern conditions, the teacher must have creative qualities. In modern conditions, the teacher must have creative qualities. This can be seen in the studies of Bronson, Merryman (2010), Ken Robinson (2007), Fisher, Frey (2008), Begetto, Kaufman (2013), Ali (2011), Treffinger (2008), etc.
The video "Does school ruin creativity?" By Ken Robinson in 2007 was watched 5 million times on YouTube.

Despite the great work done, many teachers still have no experience on how to effectively create creative qualities in themselves and in students. This will contribute to the professional development of both students and teachers. Practical actions will create for students a need for success, striving for progress and expanding their cognitive abilities. However, by the end of the school year in higher education there are no positive results. Many students have lost interest in education. As a result, teachers still do not want to organize professional activities. Although the educational authorities have taken new measures to change the activities of students who do not want to study and those who do not want to educate such students, the situation remains the same. What is the reason? Perhaps preplanned and planned lessons are not interesting for students, but the fact that the content of the education is formed does not give students any incentive. Refusal from preliminary planning of lessons, the formation and development of critical, creative thinking of students, their creative thinking, the emergence of new ideas will be a key factor in changing attitudes towards education and encouraging them to succeed. The missing factor in learning is creativity. ${ }^{1}$

\footnotetext{
${ }^{1}$ Drapeau Patti. Sparking student creativity (practical ways to promote innovative thinking and problem soving). - Alexandria - Virginia, USA: ASCD, 2014. - p. 4
} 


\section{SJIF Impact Factor: 6.260| ISI I.F.Value:1.241| Journal DOI: 10.36713/epra2016 ISSN: 2455-7838(Online) EPRA International Journal of Research and Development (IJRD)}

To fully understand the general nature of the process of creative development in a person, you must first understand the meaning of the concept of "creativity". Many studies have different views on the relationship between intelligence and creativity. While one group of researchers indicates that there is no connection between them, another group claims that the level of creativity and intelligence is interconnected. The concept of "creativity" reflects cultural diversity. For Westerners, creativity is generally new. They emphasize the existence of unconventionality, curiosity, imagination, humor and freedom based on creativity. On the other hand, orientalists see creativity as a process of reviving good. Although both the West and the East have different views on krativnost, representatives of both cultures appreciate this quality and responsibility. Many teachers believe that they do not have the ability to be creative. This can be argued for two reasons: firstly, most teachers cannot adequately explain what the concept of "creativity" means; and secondly, they do not know what qualities are directly reflected on the basis of creativity. At the same time, it should be noted that each person is naturally creative. So how can teachers demonstrate that they have creativity? Here's what Patti Drapeau advises: "If you think you are not creative, I recommend that you start organizing lessons to develop creative thinking right now. In fact, the point is not only whether you are creative or creative, but that you are creatively organizing lessons and trying new ideas. "2

From Patty Drapeau 's point of view, creative thinking is, first of all, a comprehensive view of a specific problem.

Integrated thinking requires students to rely on many ideas to study assignments, assignments and assignments. On the contrary, one-sided thinking is based on only one correct idea. A one-sided and one-sided approach to the problem cannot be denied during the debate. Therefore, one-sided thinking is equally important in the formation of creativity. That is, the task is to find several solutions (multidimensional thinking) when solving the problem, and then focus on only one solution (one-way thinking), which guarantees the best result. Based on the foregoing, the concept of "creativity" can be interpreted as follows:

Creativity (lot. "Creative" - creative, "creative" creative, creative) - the creative ability of the individual as an independent factor characterizing the willingness to develop new ideas. Human creativity is manifested in his thinking, communication, emotions and certain actions. Creativity characterizes a person as a whole or his specific features. In addition, creativity dictates the sharpness of the mind, "ensuring the active involvement

\footnotetext{
${ }^{2}$ Drapeau Patti. Sparking student creativity (practical ways to promote innovative thinking and problem soving). - Alexandria - Virginia, USA: ASCD, 2014. - p. 10
}

of students in the educational process." Creative thinking can be reflected in any social sphere. And the teacher's creativity is reflected in the creative (creative) approach to the organization of the professional activity that he creates. In recent years, this has been reflected in the concept of "pedagogical creativity. ${ }^{3}$ " Creative pedagogy must be able to guarantee two things:

1) 1) attracting the attention of students to mastering the fundamentals of science by teachers who study subjects poorly and who find it difficult to learn;

2) to enable teachers to effectively use them in the classroom, offering strategies and tools that encourage students to think creatively and stimulate creative activity.

Although teachers lack creativity, students also have interesting and exciting ideas, but they are in no hurry to express them. For this reason, the methods used in the educational process are determined by the fact that they do not contribute to the formation of students' free and independent thinking skills. The tools and strategies recommended by the author are useful for teachers in developing students 'creative abilities and developing students' interest in learning. ${ }^{4}$

The professionalism of the teacher manifests itself in various forms. It:

Preparation of regulatory documents (DTS, curriculum and curriculum for academic subjects);

Creation of educational resources (textbook, educational and methodological manual, recommendations, glossary, encyclopedia, atlas, workbook, etc.);

Preparation of the educational process and projects of spiritual and educational work;

Formation of educational information, control and test tasks;

Make the learning process interesting, lively;

Conduct successful research;

Active presentations and conferences, presentations;

Publication of new, methodical and technical methods.

The effective organization of professional activity in these forms by the teacher depends on the degree of his creativity.

Imagine a teacher who manages the learning process with great skill and who manages it fun and exciting.

Although she does not identify herself as a creative person or creator, she is also pleased with how

\footnotetext{
${ }^{3}$ Drapeau Patti. Sparking student creativity (practical ways to promote innovative thinking and problem soving). - Alexandria - Virginia, USA: ASCD, 2014. - p. 10

4 Drapeau Patti. Sparking student creativity (practical ways to promote innovative thinking and problem soving). - Alexandria - Virginia, USA: ASCD, 2014.
} 


\section{SJIF Impact Factor: 6.260| ISI I.F.Value:1.241| Journal DOI: 10.36713/epra2016 ISSN: 2455-7838(Online) EPRA International Journal of Research and Development (IJRD)} Volume: 5 | Issue: 1 | January 2020

- Peer Reviewed Journal

she organizes the learning process, which shows her creativity and uses the methods and techniques that allow her. The more a teacher uses creative methods and techniques in the learning process, the more his selfconfidence and creative abilities. ${ }^{5}$

"Creative pedagogy" plays an important role in the development of creative qualities and skills of teachers.

Creative pedagogy - 1) a creative, creative approach to the organization of the educational process of the teacher, the development of skills for the positive solution of existing pedagogical problems; 2) a subject that explores the basics of vocational training based on the characteristics of different age groups, explaining the basics of vocational training based on the development and gradual development of students in a positive, independent approach to educational materials, the ability to promote new, creative and creative ideas in educational tasks.

Like any subject, the subject of "Creative Pedagogy" has a clear goal. The purpose of the subject "Creative Pedagogy" is the education, upbringing and development of personality. In the process of creating creative thinking among students of higher educational institutions, effectiveness will guarantee:

- pay special attention to the formation of creative thinking among university students;

- development of the theoretical foundations for the formation of creative thinking among university students;

- identification of measures for the effective use of existing opportunities for the formation of creative thinking among students of higher educational institutions;

- substantiation of the system of forms, methods and tools that help students develop their creative thinking;

- ensuring interdisciplinary ties in this process;

- creating conditions for the practical application of theoretical and pedagogical knowledge acquired by students.

The general nature of creative pedagogy is revealed by a number of concepts representing its conceptual states. It:

Creativity - human activity that determines the value and usefulness of a particular novelty and its result;

Creative person - a person who can successfully carry out the creative process and has clear creative results (products);

Creative person - a person who is creative and demonstrates creativity as a process or result and who is ready and willing to take concrete actions, promote innovations, create creative products;

\footnotetext{
${ }^{5}$ Drapeau Patti. Sparking student creativity (practical ways to promote innovative thinking and problem soving). - Alexandria - Virginia, USA: ASCD, 2014.
}

Developed Man is a person who, in the process and as a result, carries out objective creativity and can create creative products to the required extent.

Creation of a creative personality is the essence of the formation and development of sustainable personal qualities in the process of teaching creativity and selfexpression;

Creativity - the result of an activity or activity recognized by society or a specific group, the novelty, importance and usefulness of a social entity;

The upbringing of a creative person is the formation and development of a person with a creative idea, skills and abilities for its implementation on the basis of the formulation and enrichment of professional and creative activities;

Professional and creative activity - the activity of a specialist, innovative behavior characterizing the success of creative solutions to professional tasks;

Creative tasks - a system of tasks aimed at solving system situations through systematic analysis;

Professional and creative opportunity :

1) professional competence, skill;

2) mastery of the basics of professional methodology;

3 ) the level of formation of creative thinking;

4) the development of professional and creative abilities and personal qualities.

Professional creativity methodology - the doctrine of the structure, logical organization, methods and means of creativity in relation to objects and certain types of professional activity as processes and results;

Creative thinking is a type of thinking that represents the organization of the creative process and the prediction of results (products);

Creative ability - the ability of a person to organize creative activity and ensure its achievement.

Creative ability is an individualistic feature of the successful implementation of creative activity and evaluation of its effectiveness.

Creative self-activation is the full manifestation and development of one's abilities in creative activity.

The professionalism of teachers is reflected in the positive solution of professional issues and the correct assessment of their solution.

In modern conditions, "Creative Pedagogy" uses the following pedagogical research methods for the professional formation and development of a creative personality:

1. The Chat method helps enrich the student's creative potential in pedagogical observation, correctly assess the situation, create pedagogical conditions that can solve the problem, and expand the possibilities of subjects of experimental work in solving problems. Interviews are conducted individually, in a group and in bulk. It is important to make sure that the creative potential of students is fully revealed during the interview. Conditions for an effective conversation: 


\section{SJIF Impact Factor: 6.260| ISI I.F.Value:1.241| Journal DOI: 10.36713/epra2016 ISSN: 2455-7838(Online) EPRA International Journal of Research and Development (IJRD)}

1) Define the content of the questions that will be determined for the purpose of the interview, and ensure the logic and consistency between the questions;

2) the exact place and time of the interview;

3) determination of the number of participants in the conversation; respondent;

4) have specific information about the

5) have friendly relations with the interlocutor;

6) creating the conditions for the interlocutor to freely express their thoughts;

7) the achievement of clear, concise and clear questions;

8) timely analyze the data.

2. Pedagogical analysis. The purpose of this research method is to determine the level of assimilation of creativity, opportunities and skills of the selected person and the substantiation of the theoretical validity of ideas put forward by the teacher.

3. Methods of pedagogical and psychological diagnostics. Such methods serve to diagnose and evaluate the creativity and creative abilities of a person. In modern conditions, dozens of methods are used to diagnose creative abilities and human skills in organizing creative activities. Among them there are a number of methods that are practical and widely used in developed countries. Gowena's "backup model," Slosson test, Vekslerov's scale. These include the Wexler scale (WPPSI test), the Stanford elementary test, and the Torrens test (including the test of incomplete drawings).

4. Pedagogical experience (lot. "Experiment" "experiment") is used to study the possibilities of solving problems, to ensure that existing pedagogical conditions are achievable, to be able to reflect on recommendations given in practice, and determine their effectiveness.

Based on the results of pedagogical experience, general conclusions and scientific and methodological recommendations were developed.

5. The questionnaire method is enriched with evidence collected during the process of pedagogical observation and interview. The method is based on the organization of a dialogue with respondents based on systematic questions. Answers to questions are usually accepted in writing. Depending on the nature of the process, the questionnaires are as follows: 1) has openended questions (questions that allow for free, a detailed answer); 2) questionnaires with closed questions (yes, no, positive, negative, etc.).

When applying the questionnaire method, a number of conditions must be met. 1) questions should serve to clarify the nature of the problem; 2) the questions should not be big and vague; 3) questions should be based on the worldview, age and psychosocial characteristics of students; 4) sufficient time should be devoted to complete answers to questions; 5) the questionnaire should not serve as a source for compiling pedagogical and psychological characteristics of students; 6) Responses should be carefully analyzed based on specific criteria.
6. The use of the method of pedagogical observation reveals a research problem based on the educational process of educational institutions, analyzes the difference between the beginning and the end of the experiment. The PC is complex and has some unique features. Expected results can be achieved if monitoring is carried out on a clear, continuous, consistent and systematic basis. The importance of this method becomes even more important when constant pedagogical supervision serves to improve the quality of education and the formation of a creative person in a person.

7. Pedagogical qualimetry is used to monitor and effectively control the quality of education. He explores and evaluates the level of creativity and the ability to organize creative activity on the basis of various levels of tests, problem solving (case studies).

8. The method of studying the creative potential of students is used to determine the abilities of students in certain areas, abilities and CRC level in certain subjects. Students' creative work - a two-page diary, an essay, a letter, a short essay, essays, term papers, graduation papers and reports on teaching practice - are important tools for its use. The method provides the basis for the ability to see, evaluate and develop individual abilities specific to a particular student. The expert assessment method is one of the most widely used and widely used research methods in modern practice in almost all areas. In most cases, the determination of the level of creativity and creativity of a person is carried out with the participation of psychologists, teachers and representatives of the creative field. However, in the learning process, an expert group can be formed among students to assess the effectiveness of their creative approaches to educational tasks. In most cases, the determination of the level of creativity and creativity of a person is carried out with the participation of psychologists, teachers and representatives of the creative field. However, in the learning process, an expert group can be formed among students to assess the effectiveness of their creative approaches to educational tasks. This group will evaluate students' creative products and their quality. Thus, the high-quality and effective organization of educational processes in modern conditions is a social necessity. To meet this need, teachers must have a high level of professional competence, skills and qualifications. The creative approach of teachers to the learning process creates students' interest in learning and contributes to their learning activities. In addition, this creates the necessary conditions for the development of students' own creative qualities, creativity and skills as professionals. The basics of the subject "Creative Pedagogy" are the effective formation of creative abilities and creative skills among students and teachers. 


\section{REFERENCES}

1.Barysheva T.A., Zhigalov Yu.A. Psychological and pedagogical pedagogical skills - St. Petersburg: SPGUTD, 2006.

2. Bashina T.F., Ilyin E.P. Psychology of creativity, creativity, giftedness. - PBC: Peter, 2009.

3. Drapeau Patti. Sparking student creativity (practical ways to promote innovative thinking and problem soving): - Alexandria - Virginia, USA. 